\title{
A Green Synthesis of Polylimonene Using Maghnite-H+, an Exchanged Montmorillonite Clay, as Eco-Catalyst
}

\author{
Hodhaifa Derdar1,*, Mohammed Belbachir ${ }^{1}$, Amine Harrane ${ }^{1,2}$
}

${ }^{1}$ Laboratory of Polymer Chemistry, Department of Chemistry, Faculty of Exact and Applied Sciences, Oran 1 University, Ahmed Benbella, BP $N^{\circ} 1524$ El M'Naouar, 31000 Oran, Algeria ${ }_{2}^{2}$ Department of Chemistry, FSEI, University of Abdelhamid Ibn Badis-Mostaganem, Algeria

Received: 26 ${ }^{\text {th }}$ May 2018; Revised: 11st September 2018; Accepted: 22nd September 2018; Available online: 25th January 2019; Published regularly: April 2019

\begin{abstract}
A new green polymerization technique to synthesis polylimonene (PLM) is carried out in this work. This technique consists of using Maghnite- $\mathrm{H}^{+}$as eco-catalyst to replace Friedel-Crafts catalysts which are toxics. Maghnite- $\mathrm{H}^{+}$is a montmorillonite silicate sheet clay which is prepared through a simple exchange process. Polymerization experiments are performed in bulk and in solution using $\mathrm{CH}_{2} \mathrm{Cl}_{2}$ as solvent. Effect of reaction time, temperature and amount of catalyst is studied, in order to find the optimal reaction conditions. The polymerization in solution leads to the best yield $(48.5 \%)$ at $-5{ }^{\circ} \mathrm{C}$ for a reaction time of $6 \mathrm{~h}$ but the bulk polymerization, that is performed at $25^{\circ} \mathrm{C}$, remains preferred even if the yield is lower (40.3\%) in order to respect the principles of a green chemistry which recommend syntheses under mild conditions, without solvents and at room temperature. The structure of the obtained polymer (PLM) is confirmed by FT-IR and Nuclear Magnetic Resonance of proton ( $\left.{ }^{1} \mathrm{H}-\mathrm{NMR}\right)$. The glass transition temperature $\left(T_{g}\right)$ of the polylimonene is defined using Differential Scanning Calorimetry (DSC) and is between $113^{\circ} \mathrm{C}$ and $116{ }^{\circ} \mathrm{C}$. The molecular weight of the obtained polymer is determined by Gel Permeation Chromatography (GPC) analysis and is about $1360 \mathrm{~g} / \mathrm{mol}$. Copyright (C) 2019 BCREC Group. All rights reserved
\end{abstract}

Keywords: Polylimonene; Maghnite- $\mathrm{H}^{+}$; eco-catalyst; green polymerization; GPC; ${ }^{1} \mathrm{H}-\mathrm{NMR}$

How to Cite: Derdar, H., Belbachir, M., Harrane, A. (2019). A Green Synthesis of Polylimonene Using Maghnite- $\mathrm{H}^{+}$, an Exchanged Montmorillonite Clay, as Eco-Catalyst. Bulletin of Chemical Reaction Engineering \& Catalysis, 14 (1): 69-78 (doi:10.9767/bcrec.14.1.2692.69-78)

Permalink/DOI: https://doi.org/10.9767/bcrec.14.1.2692.69-78

\section{Introduction}

The most studies regarding the reactions of terpenes in organic chemistry synthesis have been reported [1], yet their applications in the domain of polymer science are still limited. A search of literature reveals that attempts have been made by chemists to expand a substitute for polyterpenes from petroleum distillates [2], but no such expand has been developed yet, as

* Corresponding Author.

E-mail: hodhaifa-27@outlook.fr (H. Derdar) most of the terpenes do not homopolymerize due to steric obstacle [3].

Terpenoids are found in the essential oils of higher plants. Monoterpenoids, ten-carbon compounds created in nature by the use of the condensation of isepentenylpyrophosphate units, are among the industrially most important of the terpenoids. The monocyclic terpene d-limonene (P-mentha-1,8-diene) is the main part of the terpenold fractions of lemon and orange oils [4]. Limonene is a monocyclic terpene existing in many essential oils extracted from citrus zest [5]. Today, limonene has been widely 
used in a wide range of products such as cosmetics, food additives, medicines and even as a green solvent [6]. Limonene based products can work as polymer modifiers for block copolymers [7-8].

The first reported polymerization of terpenes was in 1798, when Bishop Watson added a drop of sulfuric acid to produce a sticky resin [9]. However, at that time, researchers could not distinguish the interesting properties of this material, which further delayed its study for 50 years. In 1950, William Roberts studied the cationic polymerization of limonene, $\alpha$-pinene and $\beta$-pinene with Friedel-Crafts catalysts, for example $\mathrm{AlBr}_{3}$ and $\mathrm{SnCl}_{4}[10]$. By adding less than $1 \%$ of $\mathrm{AlCl}_{3}$ and $\mathrm{ZnCl}_{2}$, using toluene as solvent, a solid polymer of $\beta$-pinene was produced with an average molecular weight of about $1500 \mathrm{~g} / \mathrm{mol}$. The degree of polymerization of $\beta$-pinene, although very small, is higher to that of the other two monomers. Polymerization of $\beta$-pinene given maximum polymer yield at $-30^{\circ} \mathrm{C}$ and $\alpha$-pinene, the maximum was at $40^{\circ} \mathrm{C}$ [11].

They claimed that polylimonene had only 0.36-0.44 double bonds per repeat unit. On this basis, the conclusion was that this polylimonene was different from poly $\alpha$-pinene [11]. A considerable amount of research has since contributed enormously to our understanding of cationic polymerization of terpenes, but most have focused on $\alpha$-pinene and $\beta$-pinene [12]. The copolymerization of limonene with other monomers (styrene) has been attempted, using Azobisisobutyronitrile as a radical catalyst [13].

Generally almost all the catalysts used for the preparation of polymers present great envi-

Table 1. Chemical composition of Raw-Maghnite and Maghnite- $\mathrm{H}^{+}$[23]

\begin{tabular}{ccc}
\hline Species & $\begin{array}{c}\text { Raw Maghnite } \\
\text { (wt \%) }\end{array}$ & $\begin{array}{c}\text { Maghnite- } \mathrm{H}^{+} \\
\text {(wt \%) }\end{array}$ \\
\hline $\mathrm{SiO}_{2}$ & 69.3 & 71.7 \\
$\mathrm{AL}_{2} \mathrm{O}_{3}$ & 1.16 & 0.71 \\
$\mathrm{Fe}_{2} \mathrm{O}_{3}$ & 0.3 & 0.28 \\
$\mathrm{MgO}$ & 0.5 & 0.21 \\
$\mathrm{CaO}$ & 1.07 & 0.80 \\
$\mathrm{Na} 2 \mathrm{O}$ & 0.79 & 0.77 \\
$\mathrm{~K}_{2} \mathrm{O}$ & 0.16 & 0.15 \\
$\mathrm{TiO}_{2}$ & 0.91 & 0.34 \\
\hline
\end{tabular}

ronmental problems, as they are corrosive. The main drawbacks of the application of zinc and silver compounds as well as Lewis acids are difficult to handle and their separation is complicated, which are often destroyed in this process. Moreover, zinc or silver compounds require environmental reconditioning [14].

By examining the literature, we find that the studies of the catalytic properties of natural clay for polymerization of Limonene are practically nonexistent. The main purpose of this work is to synthesis a green polymer from a green raw material and to investigate the catalytic properties of a natural clay $\left(\mathrm{Mag}-\mathrm{H}^{+}\right)$ as new and non-toxic catalyst for the polymerization of Limonene, in our previously published work we have shown the advantage of different applications of this catalyst type in several polymerization reactions [15-18]. It is preferred for its many advantages such as very low purchase price compared to other catalysts and the easy removal of the reaction mixture, regenerated by heating to a temperature above $100{ }^{\circ} \mathrm{C}$ [19-20]. In this work a very detailed study on the catalytic properties of Algerian clay $\left(\mathrm{Mag}-\mathrm{H}^{+}\right)$is developed and based on the results obtained, a possible mechanism of the polymerization reaction was proposed. FT-IR, ${ }^{1} \mathrm{H}-\mathrm{NMR}, \mathrm{DSC}$, and GPC analysis show that the polylimonene is successfully obtained.

\section{Materials and Method}

\subsection{Materials}

(R)-(+)-Limonene (97\%), Methanol $\left(\mathrm{CH}_{3} \mathrm{OH}\right.$, 99.9\%) and Dichloromethane $\left(\mathrm{CH}_{2} \mathrm{Cl}_{2}, 99.8 \%\right)$ are supplied by Sigma Aldrich and used as received. Maghnite (Algerian montmorillonite) is supplied in the raw state by ENOF Bental Spa of the National Company of Nonferrous Mining Products, Maghnia Unit (Algeria).

\subsection{Preparation of Maghnite- $\mathrm{H}^{+}$}

Maghnite- $\mathrm{H}^{+}$is prepared according to the process reported in our previous study [21-22]. Maghnite- $\mathrm{H}^{+}$is activated with a sulfuric acid solution to give a Maghnite exchanged with protons, called Mag- $\mathrm{H}^{+}$. In an Erlenmeyer flask, crushed raw Maghnite $(20 \mathrm{~g})$ is dispersed in a volume of distilled water $(120 \mathrm{ml})$. The mixture is stirred $2 \mathrm{~h}$ at room temperature. Then, a solution of sulfuric acid $(0.25 \mathrm{M})$ is added. The solution thus obtained is maintained for two days under stirring. The mineral is filtered off and washed several times with distilled water up to $\mathrm{pH}$ 7. After filtration, Mag- $\mathrm{H}^{+}$is dried in an oven for $24 \mathrm{~h}$, at $105^{\circ} \mathrm{C}$ 
and is then crushed. The composition of raw and treated Maghnite is given in Table 1 and the results show that the acid treatment leads to a decrease in $\mathrm{Al}_{2} \mathrm{O}_{3}$ concentration and silica enrichment in the material. The results also show a decrease in impurity levels such as iron oxide and calcite. Its structure is established by FT-IR and XRD.

\subsection{Synthesis of Polylimonene Catalyzed by Maghnite- $\mathrm{H}^{+}$}

The reaction of polymerization of limonene is carried out, in the first place, in bulk using Mag- $\mathrm{H}^{+}$as catalyst. In a flask containing $2 \mathrm{~g}$ $(0.01 \mathrm{~mol})$ of limonene, we added an amount of $10 \%$ in weight of $\mathrm{Mag}-\mathrm{H}^{+}$which is previously dried for 30 minutes in the oven at $105{ }^{\circ} \mathrm{C}$. The mixture is stirred for $6 \mathrm{~h}$ at room temperature $\left(25^{\circ} \mathrm{C}\right)$. The product turned orange when the catalyst is added. Furthermore, it becomes darker and more viscous with the time of polymerization. After $6 \mathrm{~h}$, the reaction mixture is dissolved in $\mathrm{CH}_{2} \mathrm{Cl}_{2}$, then filtered, precipitated in cold Methanol $\left(\mathrm{CH}_{3} \mathrm{OH}\right)$ and dried in vacuum over night. Then, the same experimental protocol is performed with $10 \% \mathrm{wt}$ of $\mathrm{Mag}-\mathrm{H}^{+}$, but this time, in solution using dichloromethane as solvent at various temperature. The \% yield of<smiles>C=C(C)C1CC=C(C)CC1</smiles>

Limonene

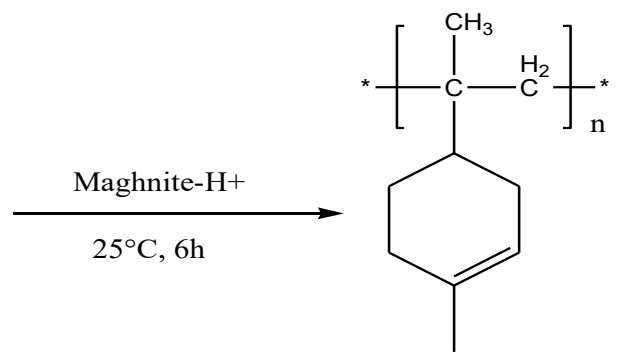

Polylimonene
Scheme 1. Polymerization of Limonene catalyzed by Mag- $\mathrm{H}^{+}$

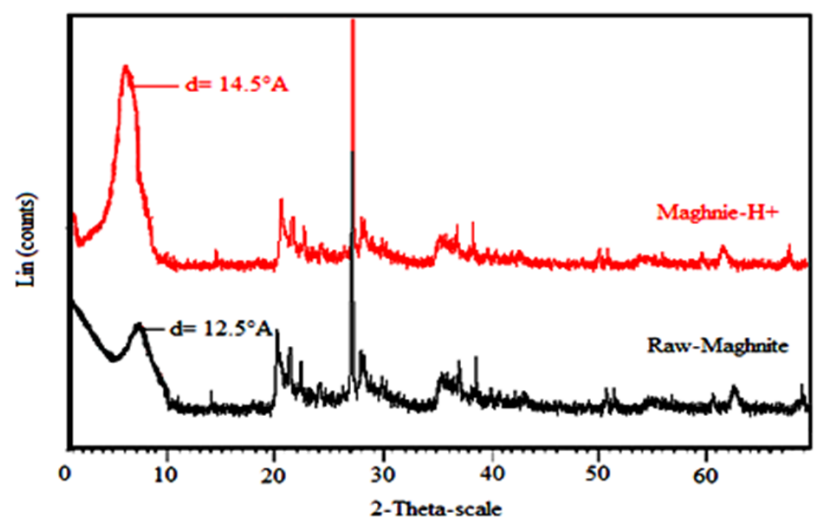

Figure 1. X Ray diffractogram of Raw-Maghnite (black) and Maghnite- $\mathrm{H}^{+} 0.25 \mathrm{M}$ (red) the obtained polymer is calculated by a simple weighing according to the following equation:

$$
\text { Yield }(\%)=\left(M_{o} / M_{1}\right) .100 \%
$$

where, $M_{0}$ is weight of the obtained polymer, $M_{1}$ is weight of the initial monomer. The polymerization reaction of limonene is described in Scheme 1.

\subsection{Characterization}

The X-Ray powder diffraction profiles for pressed powder samples were recorded on a $\mathrm{D} 8$ Discover Bruker diffractometer using $\mathrm{Cu}-\mathrm{K} \alpha$ radiation $(\lambda=1.5418 \AA)$. FTIR absorption spectra were recorded on an Alpha Bruker FTIR spectrometer. NMR is a very powerful analytical method for the elucidation of chemical structures. ${ }^{1} \mathrm{H}-\mathrm{NMR}$ spectra are recorded on a Brucker-Avance 400 MHZ apparatus in Deuterated Chloroform. Polymer thermal stability was assessed using calorimetric analysis (DSC) 204 F1, NETZSCH equipment, under an inert atmosphere with a flow rate of 50 $\mathrm{mL} / \mathrm{min}$. The heating rate was $10^{\circ} \mathrm{C} / \mathrm{min}$ from ambient to $800{ }^{\circ} \mathrm{C}$ under $\mathrm{N}_{2}$ and the sample weighed about $6 \mathrm{mg}$. SEC analyses were carried out on GPC-PL120 apparatus, using $\mathrm{CH}_{2} \mathrm{Cl}_{2}(1.0 \mathrm{~mL} / \mathrm{min})$ as the mobile phase at $27.5{ }^{\circ} \mathrm{C}$, Polystyrene standards were used for column calibration.

\section{Results and Discussion}

\subsection{Characterization of Maghnite- $\mathrm{H}^{+}$}

X-Ray diffractogrammes of Raw-Mag and Mag- $\mathrm{H}^{+}$are shown in Figure 1. The calculated basal spacing ( $\left.\mathrm{d}_{001}\right)$ from XRD patterns, applying Bragg equation $(2 d \sin \theta=n \lambda)$ is $12.5 \AA$ for Raw-Mag and 14.5 ̊ for Mag- $\mathrm{H}^{+}$. This increase

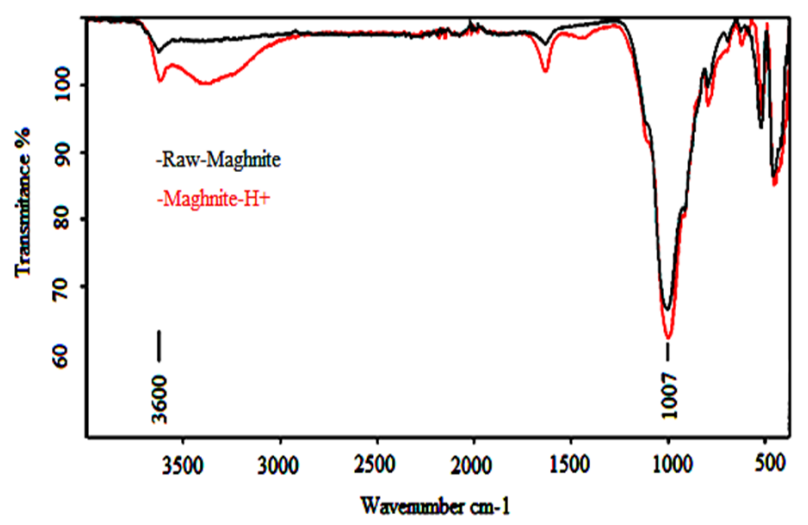

Figure 2. FT-IR spectrum of Raw-Maghnite (red) and Maghnite- $\mathrm{H}^{+} 0.25 \mathrm{M}$ (black) 
in basal spacing is explained by the substitution of single water between the sheet of RawMag by two interlamellar water layer in Mag$\mathrm{H}^{+}$.

FT-IR spectrum of Maghnite- $\mathrm{H}^{+}$(Figure 2) is recorded in order to check the quality of the catalyst preparation. The hydrated structure of Maghnite- $\mathrm{H}^{+}$results in characteristic vibrations of hydroxyl groups around $3400 \mathrm{~cm}^{-1}$ and $3600 \mathrm{~cm}^{-1}$. Various Si-O vibrations mode at $1007 \mathrm{~cm}^{-1}, 756 \mathrm{~cm}^{-1}, 518 \mathrm{~cm}^{-1}$, and $449 \mathrm{~cm}^{-1} \mathrm{can}$ be attributed to the montmorillonite clay structure. All these expected absorption bands confirm that the structure of the compound is thus in good agreement with vibration values obtained from the literature [24].

\subsection{Characterization of the Obtained Polylimo- nene (PLM)}

\subsubsection{Fourier Transform Infrared Spectroscopy (FT-IR)}

FT-IR spectrum of limonene and its polymer have been shown, respectively, in Figure 3a and $3 \mathrm{~b}$. It is observed that the peaks at 1309 , $1217,956,913$, and $885 \mathrm{~cm}^{-1}$ corresponding to the double bonds in limonene (Figure $3 \mathrm{a}$ ) have disappeared in the spectra of PLM (Figure 3b) confirming that the polymerization has succeeded. It should be noted the presence of characteristic band corresponding to the stretching band of $\mathrm{C}=\mathrm{C}$ at $1640 \mathrm{~cm}^{-1}$ in the spectra of limonene and at $1673 \mathrm{~cm}^{-1}$ in the spectra of PLM and also an intense band at $2930 \mathrm{~cm}^{-1}$ corresponding to the valence vibration of the methylene $\mathrm{C}-\mathrm{H}$ bond in both FT-IR spectrum.

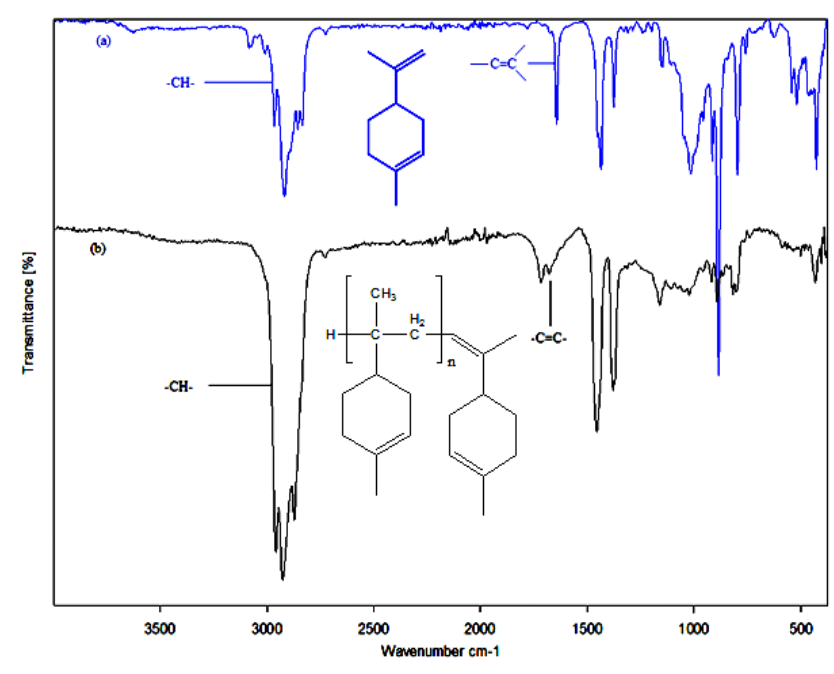

Figure 3. FT-IR spectrum of (a) limonene and (b) polylimonene catalyzed by $10 \% \mathrm{wt}$ of $\mathrm{Mag}-\mathrm{H}^{+}$

\subsubsection{Nuclear Magnetic Resonance of proton ( $\left.{ }^{1} \mathrm{H}-\mathrm{NMR}\right)$}

${ }^{1} \mathrm{H}-\mathrm{NMR}$ spectra of the obtained polylimonene is shown in Figure 5. The polymerization is carried out in bulk, at $25^{\circ} \mathrm{C}$, for 6 hours. The peak "c" at $1.4 \mathrm{ppm}$ corresponding to protons in methyl group (C-H) in limonene (Figure 4) moves to $0.81 \mathrm{ppm}$ for PLM (Figure 5). There is also the appearance of the peak "f" at $1.18 \mathrm{ppm}$ in the spectrum of the PLM corresponding to the protons of methylene group $\left(-\mathrm{CH}_{2}\right)$, this peak doesn't appear in the spectrum of Limonene. The peak "a" at $5.35 \mathrm{ppm}$ assigned to the internal double bond $(\mathrm{C}=\mathrm{C})$ has an integration of 1 in the limonene spectrum, this same peak has an integration of 2 in the PLM spectrum confirming that there are two internal double bonds $(\mathrm{C}=\mathrm{C})$ : polymer and end of chain. The peak "b" at $4.63 \mathrm{ppm}$ is the characteristic resonance of the protons resulted by the terminal double bond $(-\mathrm{C}=\mathrm{CH})$.

The integration of this peak in the spectrum of PLM is 1 (only 1 proton) whereas in the spectrum of limonene, the integration of this peak is 2 ( 2 protons) confirming that the double bond $(-\mathrm{C}=\mathrm{CH}))$ of limonene has changed into chain end in the PLM. In addition, the integration of the peak "c", which is 63.51 compared to 1 of the end of chain, clearly shows that the polymerization of limonene is successful with Maghnite- $\mathrm{H}^{+}$.

\subsubsection{Scanning Calorimetry (DSC)}

The thermal properties of the obtained polymer (PLM) are determinate by Differential Scanning Calorimetry (DSC). Figure 6 shows the results of the DSC measurements. The

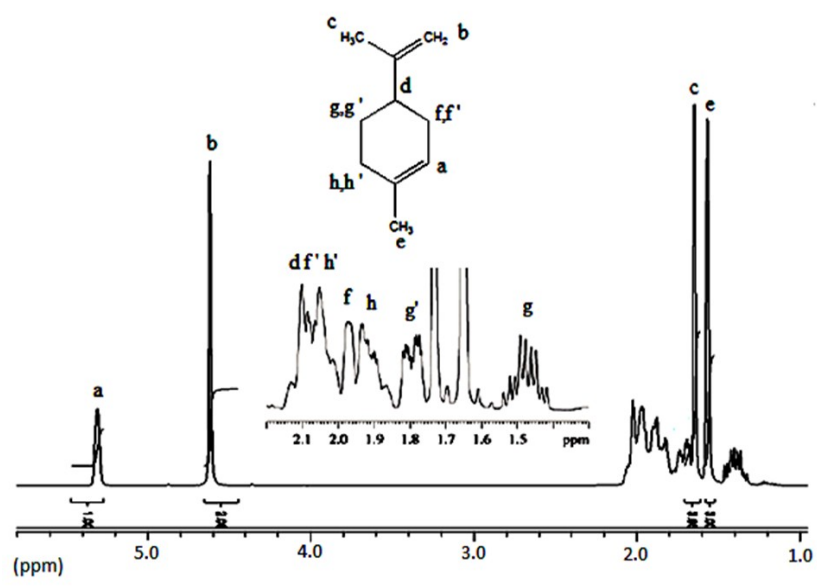

Figure 4. ${ }^{1} \mathrm{H}-\mathrm{NMR}$ spectrum of limonene (in $\mathrm{CDCl}_{3}, 400 \mathrm{MHZ}$ ) 


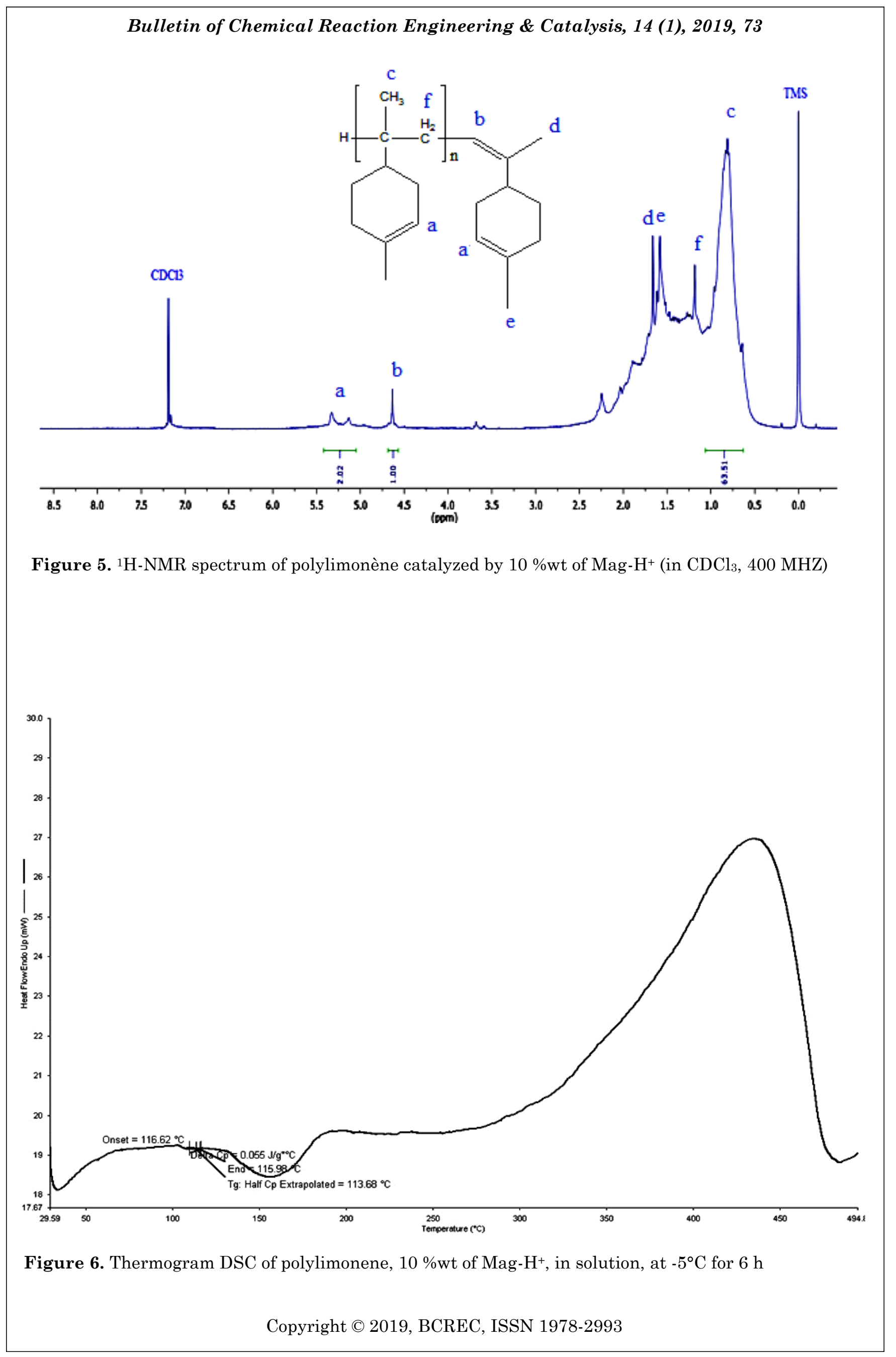


glass transition temperature $\left(T_{g}\right)$ of the PLM is observed in the temperature range of 113-116 ${ }^{\circ} \mathrm{C}$, the same result was obtained by Singh and Kamal [25].

\subsection{Kinetic Study of the Polymerization of Limonene Catalyzed by $\mathrm{Mag}-\mathrm{H}^{+}$}

The objective of this part is to study the kinetic of the polymerization of limonene by Maghnite- $\mathrm{H}^{+}$, which consists in varying separately different parameters including the quantity of the catalyst, the reaction time and the temperature, in order to know their influence on the yield of the obtained product and to find the optimum conditions of the reaction. In a previous work [26-27] we have demonstrated that there is a correlation between acid activa-

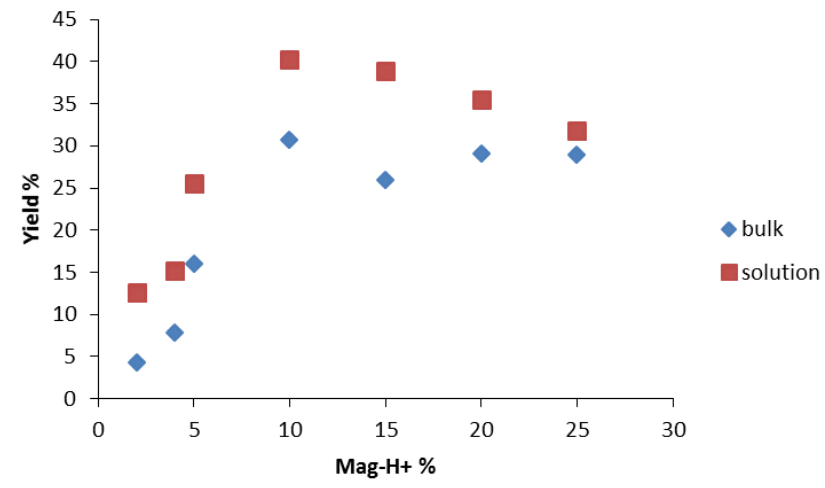

Figure 7. Effect of $\mathrm{Mag}-\mathrm{H}^{+}$amount on the yield of PLM (in solution and in bulk), at $25^{\circ} \mathrm{C}$ for $6 \mathrm{~h}$ tion of Maghnite with different $\mathrm{H}_{2} \mathrm{SO}_{4}$ concentrations and its catalytic activity. We found that the best results are obtained by acid activation with $0.25 \mathrm{M} \mathrm{H}_{2} \mathrm{SO}_{4}$ solution in which there is a complete cationic exchange of Maghnite by protons, without the destruction of its structure.

\subsubsection{Effect of Mag- $\mathrm{H}^{+}$amount on the yield of PLM}

The polymerization is carried at $25^{\circ} \mathrm{C}$ for 6 $\mathrm{h}$, using various amounts of $\mathrm{Mag}-\mathrm{H}^{+}$. The results in Figure 7 show that the yield of polymer increased with the amount of $\mathrm{Mag}-\mathrm{H}^{+}$for both polymerizations, in solution and in bulk. The output increases according to the quantity of Mag- $\mathrm{H}^{+}$up to the optimal point, which corre-

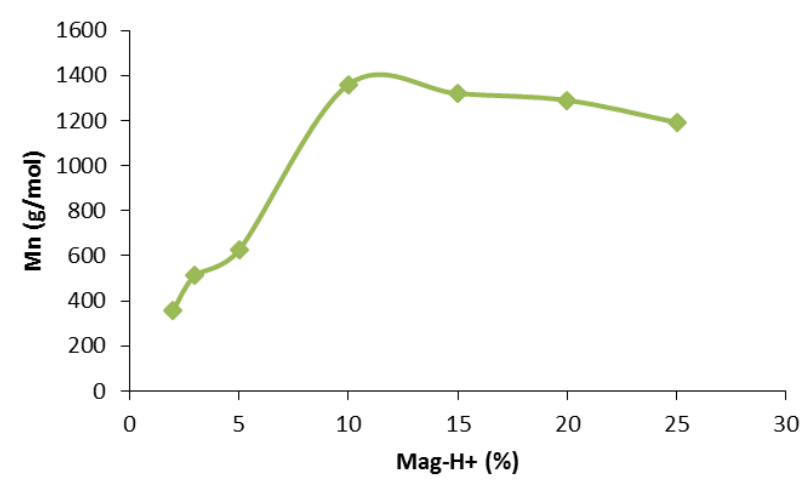

Figure 8. Effect of Mag- $\mathrm{H}^{+}$amount on average molar mass (Mn) of PLM, in solution, at $25^{\circ} \mathrm{C}$ for $6 \mathrm{~h}$

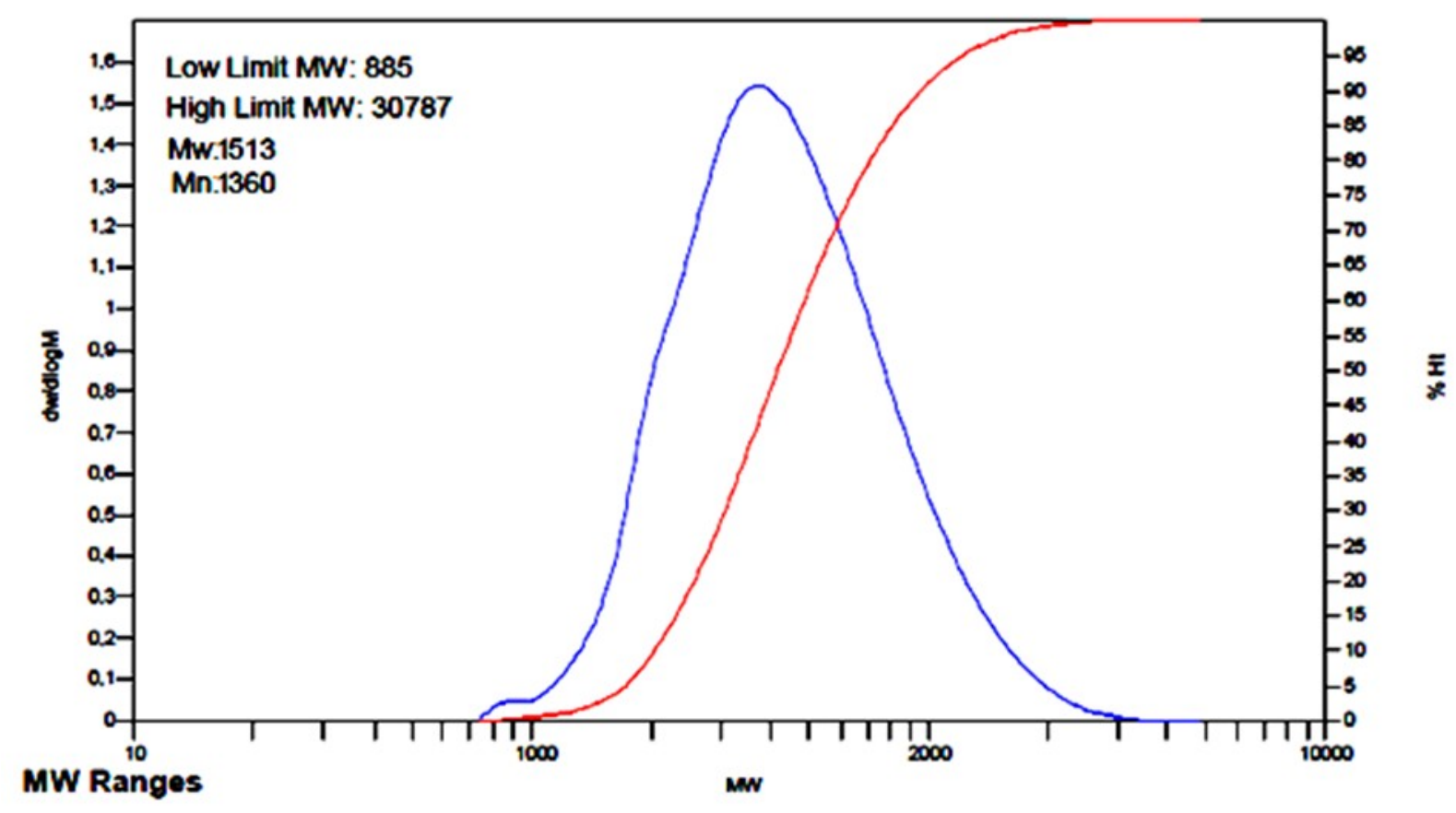

Figure 9. GPC Chromatogram of the obtained polylimonene 
sponds to $10 \%$. This behavior is explained by the increase of active sites available in Maghnite- $\mathrm{H}^{+}$responsible for the initiation and acceleration of the polymerization reaction until the saturation of these sites. The obtained results show also that the viscosity of the environment in the bulk polymerization limits the growth of polylimonene giving lower yields compared to those of limonene polymerized in solution. However, bulk polymerization remains a preferred technique for PLM synthesis to be consistent with the principles of green chemistry.

Figure 8 shows the effect of the amount of Mag- $\mathrm{H}^{+}$on the $\mathrm{Mn}$ of the obtained polymer (PLM), using various amounts of Mag- $\mathrm{H}^{+}(2,4$, $5,10,15,20$, and $25 \%$ by weight). The polymerization of limonene is carried out in solution at $25^{\circ} \mathrm{C}$, for $6 \mathrm{~h}$. The amount of the catalyst $\left(\mathrm{Mag}-\mathrm{H}^{+}\right)$is an important factor of polymerization. In fact, the results summarized in Figure 8 show that a critical value of $10 \%$ wt of catalyst seems to limit the increase of molar masses $(\mathrm{Mn}=1360 \mathrm{~g} / \mathrm{mol})$. An amount higher than 10 $\%$ wt of Maghnite- $\mathrm{H}^{+}$leads to the degradation of the polymer giving lower Mn. GPC analysis of PLM synthesized with $10 \% \mathrm{wt}$ of $\mathrm{Mag}-\mathrm{H}^{+}$, in solution, at $-5{ }^{\circ} \mathrm{C}$ for $6 \mathrm{~h}$, is also provided to gives the molecular weight of the product. Figure 9 shows that $\mathrm{Mn}=1360 \mathrm{~g} / \mathrm{mol}$ and $\mathrm{Mw}=1513$ $\mathrm{g} / \mathrm{mol}$.

\subsubsection{Effect of the temperature on the yield of PLM}

Figure 10 shows the effect of temperature on the yield of the polymerization. This study is carried out in solution and in bulk at different temperatures: $-15,-5,0,15,15,20$, and $25^{\circ} \mathrm{C}$, for $6 \mathrm{~h}$ with $10 \% \mathrm{wt}$ of Mag- $\mathrm{H}^{+}$. An interesting result is that Maghnite- $\mathrm{H}^{+}$is able to initiate limonene polymerization even at low temperature both in bulk and with $\mathrm{CH}_{2} \mathrm{Cl}_{2}$. The yield of

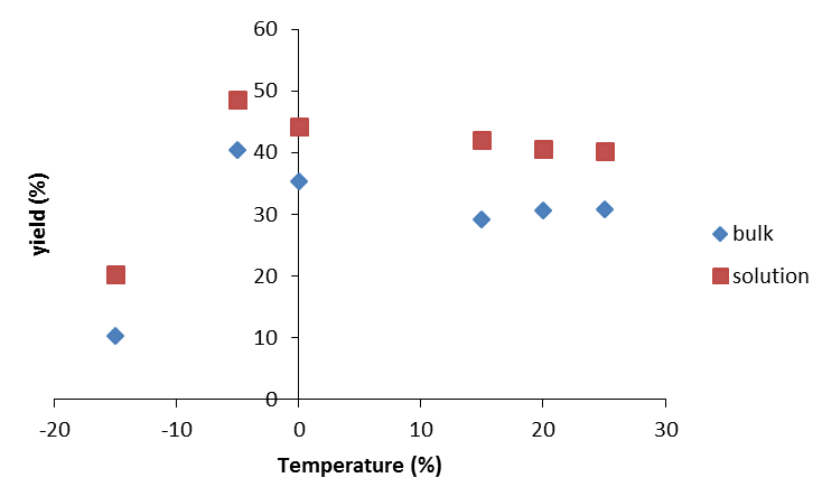

Figure 10. Effect of Temperature on the yield of PLM (in solution and in bulk), $10 \%$ wt of $\mathrm{Mag}-\mathrm{H}^{+}$, for $6 \mathrm{~h}$ the reaction reaches its maximum $(40.5 \%$ in bulk, $48.5 \%$ in solution) for a temperature of -5 ${ }^{\circ} \mathrm{C}$. The yield decreased with the temperature rising from 0 to $25^{\circ} \mathrm{C}$. It is noted that the temperature has a great influence on the yield.

\subsubsection{Effect of the time on the yield of PLM}

Figure 11 shows the yield of polymer versus time for the polymerization of limonene using of $\mathrm{Mag}-\mathrm{H}^{+}$as a catalyst. As the figure shows that at the end of $6 \mathrm{~h}$, polymerization takes place quickly and reaching the best yields (48.5 $\%$ in solution, $40.5 \%$ in bulk) in presence of 10 $\%$ wt of Mag- $\mathrm{H}^{+}$at $-5{ }^{\circ} \mathrm{C}$. After this time, the polymerization slows down gradually and the yield becomes almost constant.

\subsection{Proposed Mechanism of the Polymerization}

The mechanism proposed for the reaction of limonene polymerization by Maghnite- $\mathrm{H}^{+}$is based on the cationic aspect of the catalyst. The reaction of polymerization of isobutylene [26] and dioxolane [28], which polymerize only by cationic process by Maghnite confirms this cationic aspect. The initiation step occurs by the protonation of the monomer by Maghnite protons, and the platelets of Maghnite take place as a counter-ion. Propagation and termination steps occur in similar way of conventional cationic polymerization.

\section{Conclusion}

The polymerization of limonene was successfully obtained using Maghnite- $\mathrm{H}^{+}$as a green solid catalyst, in bulk and in solution. The polymerization proceeds via a cationic mechanism due to the presence of intercalated protons in the lamellar structure of Maghnite. The influencing factors on the polymerization reaction were studied, and the optimal reaction

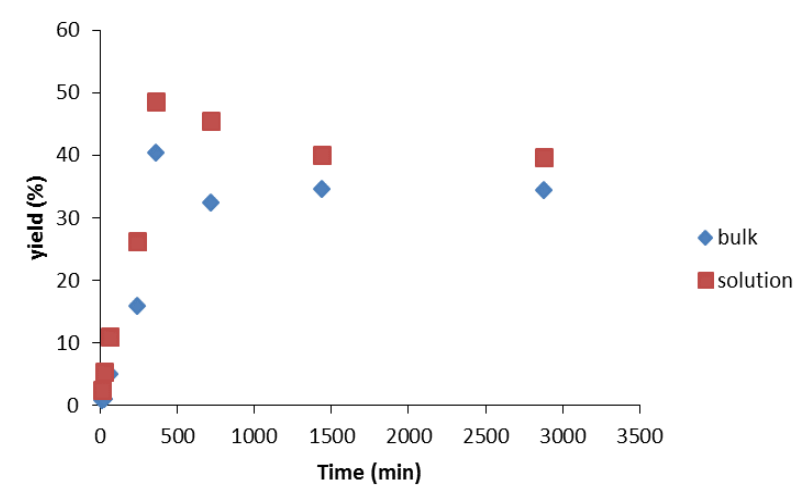

Figure 11. Effect of the time on the yield of PLM (in solution and in bulk), $10 \%$ wt of Mag$\mathrm{H}^{+}$at $-5^{\circ} \mathrm{C}$ 


\section{Initiation}

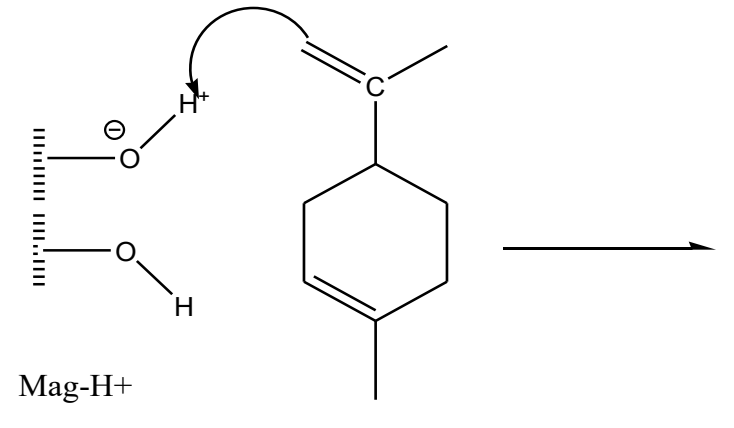

limonene

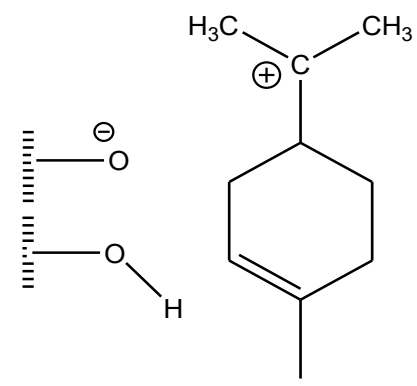

monomer with actives sites

\section{Propagation}

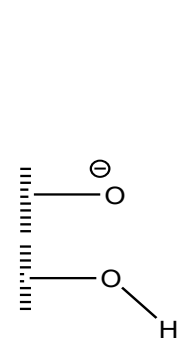<smiles>CC1=CCC(=C(C)C)CC1</smiles><smiles>C=C(C)C1CC=C(C)CC1</smiles><smiles>C=C(C)C1CC=C(C)CC1</smiles><smiles>CC1=CCC(C(C)C)CC1</smiles><smiles>CC1=CCC([C@@H](C)C(C)(C)[C@@H](C)C(C)(C)C2CC=C(C)CC2)CC1</smiles>

Termination<smiles>CC1=CCC(C(C)(C)C(C)(C)C(C)(C)C2CC=C(C)CC2)CC1</smiles><smiles>CO[C@H](C)O[PH2+]</smiles>

Mag- +<smiles>CC1=CCC(C(C)=C(C)CC(C)(C)C2CC=C(C)CC2)CC1</smiles>

polylimonene

Scheme 2. Proposed mechanism of the cationic polymerization of limonene by Maghnite- $\mathrm{H}^{+}$ 
conditions were obtained. The kinetic study of the polymerization demonstrates that the amount of catalyst increases the molecular weight of the obtained polymer (PLM). The synthesized product is perfectly characterized by FT-IR, ${ }^{1} \mathrm{H}$ NMR, GPC, and DSC analyses, and the structure of the obtained polymer has been confirmed. The results indicated that, the polymerization was successful both in solution and in bulk. The objectives of this work are the synthesis of polylimonene out of a green raw material (limonene) by the use of MMT- $\mathrm{H}^{+}$as a catalyst. The interesting aspect of this new ecological catalyst is the environmentally friendly nature of the reaction because it does not imply the disposal of solvents or metal catalysts.

\section{Acknowledgement}

The authors wish to thank Agence Thématique de Recherche en Sciences et Technologie-Algeria (ATRST) for supporting this research (Project Algero-Portugues); our portugues partner Prof. Geoffrey Mitchell and his team in CDRSP Leiria, for their collaboration, M. Benachour, Z. Cherifi, A. Zaoui, S. Benabi, B. Bouhdjer, and R. Meghabar.

\section{References}

[1] Finar, I.L. eds. (1985). The terpenoids. vol, 2, Longman, London.

[2] Keszler, B., Kennedy, J.P. (1992). Synthesis of high molecular weight poly ( $\beta$-pinene). Adv. Polym. Sci. 100: 1-9.

[3] Ham, G.E. (1964). Penultimate unit effects in terpolymerization. J. Polym. Sci. A Polym. Chem., 2: 4191-4200.

[4] Karr, L.L., Coats, J.R. (1988). Insecticidal properties of d-limonene. J. Pesticide Sci. 13: 287-290.

[5] Sun, J. (2007). D-Limonene: safety and clinical applications. Alternat. Med. Rev., 12: 259264.

[6] Mathers, T., Damodaran, K. (2007). Renewable chain transfer agents for metallocene polymerizations: The effects of chiral monoterpenes on the polyolefin molecular weight and isotacticity. J. Polym. Sci. A Polym. Chem. 45: 3150-3165.

[7] Wilbon, P.A., Fuxiang, C., Chauanbing, T. (2013). Progress in Renewable Polymers from Natural Terpenes, Terpenoids, and Rosin. Macromol. Rapid. Commun. 34: 8-37.

[8] Kotaro, S., Masaru, M., Kanji, N., Masami, K. (2010). AAB-Sequence Living Radical Chain Copolymerization of Naturally Occurring
Limonene with Maleimide: An End-to-End Sequence-Regulated Copolymer. J. Am. Chem. Soc. 132: 10003-10005.

[9] Rukel, E., Wojcik, R., Arlt, H. (1976). Cationic Polymerization of $a$-Pinene Oxide and $\beta$-Pinene Oxide by a Unique Oxonium lonCarbenium Ion Sequence. J. Macromol. Sci. Part A, 10: 1371-1390.

[10] Roberts, W., Day, A. (1950). A Study of the Polymerization of $\alpha$-and $\beta$-Pinene with Friedel-Crafts Type Catalysts. J. Am. Chem. Soc. 72: 1226-1230.

[11] Modena, M., Bates, R., Marvel, C. (1965). Some low molecular weight polymers of d-limonene and related terpenes obtained by Ziegler-type catalysts. J. Polym. Sci. A Polym. Chem. 3: 949-960.

[12] Barros, M.T., Petrova, K.T., Ramos, A.M. (2007). Potentially Biodegradable Polymers Based on $\alpha$ - or $\beta$-Pinene and Sugar Derivatives or Styrene, Obtained under Normal Conditions and on Microwave Irradiation. Eur. J. Org. Chem. 8: 1357-1363.

[13] Sharma, S., Srivastava, K.A. (2004). Synthesis and characterization of copolymers of limonene with styrene initiated by azobisisobutyronitrile. Eur. Polym. J. 40: 2235-2240.

[14] Hensen, K., Mahaim, C., Hislderich, W.F. (1997). Alkoxylation of limonene and alphapinene over beta zeolite as heterogeneous catalyst, Appl. Catal. A 149: 311-329.

[15] Belbachir, M., Bensaoula, A. (2006). US. Patent $\mathrm{N}^{\circ} 7,094,823$.

[16] Baghdadli, M.C., Meghabar, R., Belbachir, M. (2016). Acid-Activated Algerian Montmorillonite as Heterogeneous Catalysts for Cationic Polymerization of Styrene. Asia J. Chem. 28:1197-1204.

[17] Yahiaoui, A., Belbachir, M. (2006). Ring-opening polymerization of styrene oxide with Maghnite- $\mathrm{H}^{+}$as ecocatalyst. J. Appl. Polym. Sci. 100: 1681-1687.

[18] Ferrahi, M.I., Belbachir, M. (2006). Cyclic polyesters prepared by poly (oxypropylene oxymaloyl) ring-chain reactions. Express Polym. Lett. 1: 24-26.

[19] Belbachir, M., Bensaoula, A. (2001). US. Patent No 6,274,527B1

[20] Belbachir, M., Bensaoula, A. (2001). US. Patent 066969.0101

[21] Draoua, Z., Harrane, A., Belbachir, M. (2015). Amphiphilic Biodegradable Poly( $\epsilon$-caprolactone)-Poly(ethylene glycol) - Poly( $\epsilon$-caprolactone) Triblock Copolymer Synthesis by Maghnite- $\mathrm{H}^{+}$as a Green Catalyst. J. Macromol. Sci. Part A, 52: 130-137 
[22] Bennabi, S. (2017). New approach for synthesis of poly(ethylglyoxylate) using Maghnite$\mathrm{H}^{+}$, an Algerian proton exchanged montmorillonite clay, as an eco-catalyst. J. Macromol. Sci. Part A, 54: 1-10.

[23] Hennaoui, F., Belbachir, M. (2015). A Green One-pot Synthesis of PDMS BisMacromonomers Using an Ecologic Catalyst (Maghnite-H+). J. Macromol. Sci. Part A, 52: 992-1001.

[24] Cicel, B. (1992). Mineralogical composition and distribution of $\mathrm{Si}, \mathrm{Al}, \mathrm{Fe}, \mathrm{Mg}$ and $\mathrm{Ca}$ in the fine fractions of some Czech and Slovak bentonites. Carpath. Ser. Clays, 43: 3-7.

[25] Singh, A., Kamal, K. (2012). Synthesis and characterization of polylimonene: Polymer of an optically active terpene. J. Appl. Polym. Sci. 125: 1456-1459.
[26] Harrane, A., Meghabar, R., Belbachir, M. (2002). A Protons Exchanged Montmorillonite Clay as an Efficient Catalyst for the Reaction of Isobutylene Polymerization. Int. J. Mol. Sci. 3: 790-800.

[27] Harrane, A., Meghabar, R., Belbachir, M. (2006). Kinetics of the ring opening polymerization of $\varepsilon$-caprolactone catalysed by a proton exchanged montmorillonite clay. React. Funct. Polym. 66: 1696-1702.

[28] Megherbi, R., Belbachir, M., Meghabar, R. (2006). Maghnite- $\mathrm{H}^{+}$as a cationic catalyst in the synthesis of poly(1,3-dioxolane) and a, $\omega$-methacryloyloxy-poly (1,3-dioxolane) . J. Appl. Polym. Sci. 101: 78-82. 